CATALAN REVIEW

Catalan Review

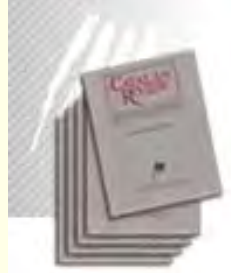

You are accessing the Digital Archive of the Catalan Review Journal.

By accessing and/or using this Digital Archive, you accept and agree to abide by the Terms and Conditions of Use available at http://www.nacs-

catalanstudies.org/catalan_review.html

Catalan Review is the premier international scholarly journal devoted to all aspects of Catalan culture. By Catalan culture is understood all manifestations of intellectual and artistic life produced in the Catalan language or in the geographical areas where Catalan is spoken. Catalan Review has been in publication since 1986 .
NORTH

AMERICAN

CATALAN

SOCIETY
Esteu accedint a l'Arxiu Digital del Catalan Review

A l' accedir i / o utilitzar aquest Arxiu Digital, vostè accepta i es compromet a complir els termes i condicions d'ús disponibles a http://www.nacs-

catalanstudies.org/catalan_review.html

Catalan Review és la primera revista internacional dedicada a tots els aspectes de la cultura catalana. Per la cultura catalana s'entén totes les manifestacions de la vida intel lectual i artística produïda en llengua catalana o en les zones geogràfiques on es parla català. Catalan Review es publica des de 1986.

\title{
Contemporary Catalonia as an Enigma Robert Kirsner
}

Catalan Review, Vol. III, number 1 (1989), p. 99-108 


\section{CONTEMPORARY CATALONIA AS AN ENIGMA}

\section{ROBERT KIRSNER}

In 20 th century Spain friends and foes alike have shared a common vision of Catalonia. Whether awed by the accomplishments of the industrious Catalans or whether offended by their persistent quest for recognition of autonomy, fellow Spaniards basically have not grasped the uniqueness of the Catalan people. ${ }^{1}$ While interested writers have succeeded in establishing the irreducible ethnicity of the Basques, (Unamuno has been the chief "propagandist»), the question of Catalan distinctiveness remains muddled, at times completely ignored, and more often than not indulgently accepted. This situation prompted Américo Castro to write in the fourth edition of his monumental La realidad histórica de España, "el castellano ha de confesarse con el catalán y viceversa». ${ }^{2}$ The words of the sage give testimony to the intellectual exile Catalonia has endured in Spain, especially among those who live under the Castilian hegemony.

The words of Américo Castro, as has been pointed out by Horst Hina, author of the penetrating study, Castilla $y$ Cataluña en el debate cultural I7I4-I739, appeared only in the fourth edition of Castro's opus. In the r954 edition, also noted by Hina, Castro assumed the position that Catalonia had not been a complete

${ }^{1}$ Unlike the Basques, most Catalans see themselves as Spaniards. Relying on surveys and statistics provided by the magazine, Cambio I6 (April Is, 1985), Joaquim Roy points out in a manuscript which is being prepared for his book, $A$ Decade of Linguistic Normalization in Catalonia (1977-1987), that there is a seven percent hard core of Catalans who see themselves only as Catalans.

${ }^{2}$ The words of Américo Castro are cited by Horst Hina in his book, Castillay Cataluña en el debate cultural I7I4-1939, Historia de las relaciones ideológicas catalanocastellanas, versión castellana de Ricard Wilshusen. (Barcelona: Ediciones Península, 1986), p. Ir. (All subsequent citations from Hina's work will be from the same edition and will appear with the number of the appropriate pages in parentheses following the quotes). 
component of Spain. Interestingly, the assertion was contained only in the 1954 edition: «En resolución, Cataluña no perteneció nunca totalmente a España, ni tampoco dejó de pertenecer a ella; un drama desgarrador que sólo viviendo a España desde dentro de su historia cabe entender en su integridad" (408). Castro's exhortation to his compatriots regarding "el enfrentamiento con la realidad histórica" creditably applied to himself. What he had been asking Spaniards to do, to confront the realities of their history, he faced himself. The modified focus on Catalonia gives evidence to his having practiced what he preached. Américo Castro was always in the process of rethinking and reworking his ideas on history, literature and philology. His scholarship was dynamic; he did not rest on his laurels, ever. His eventual conclusion that Castilians and Catalans should make an effort to understand one another constitutes an admission that the Catalan "forma de vida" has not been adequately appreciated, that much of the duality of Catalan existence remains a puzzle for non-Catalan Spaniards.

Specifically on the question of linguistic pride, the distinguished philosopher, Julián Marias, has evinced the lack of sensitivity which prevails on the part of the non-Catalan Spaniards, even when there is good will.

... Cataluña se siente "lingüísticamente dolorida"... Los Catalanes se han proyectado en estos años, seguramente más que en ningún otro periodo de la historia, en la lengua catalana; se sienten identificados con ella y con su destino...

Los españoles no catalanes no saben bien cuál es la situación efectiva: no se dan cuenta ni de la importancia vital que el catalán tiene para cuantos lo hablan desde la cuna, ni de las dificultades con que tropiezan para aprenderlo, para llegar a hablarlo bien, para tener esa primera instalación radical en que se funda toda la vida intelectual, afectiva, en suma...

Algunos catalanes han objetado a mi imagen de la "casa lingüística" del hombre de Cataluña, una de "dos pisos", uno, el catalán, aquél en que se hace la vida más fundamental y entrañable; otro, el "castellano" o 
"español», al cual se va cotidianamente incontables veces, permaneciendo "en casa". ${ }^{3}$

Nonetheless, at the same time that Marías seems to recognize the forgetfulness into which Catalonia has been cast, he establishes the lack of a Catalonian literary tradition when compared to Castilian accomplishments. Further, he adds a personal wounding note when he affirms that he prefers the term «lengua española" to "castellana." "... quiero decir que a nadie en su juicio y espíritu leal se le ocurriría enfrentar lo que se ha escrito en catalán entre 1500 y I850 con la literatura en lengua castellana - o como yo prefiero decir, española - ..." (r68). Small wonder that a book by a Catalan was writen as a answer to Julián Marías: Realidad de Cataluña. Respuesta a Julián Marías (The subtitle is printed in red) by Maurici Serrahima. After citing some limited favorable aspects of Marías'work, Serrahima begins his refutation. For the Catalans, Catalonia is not a mere region. That affirmation could well become the first commandment for understanding Catalonian existential reality. "... Es decir, que sea cual fuere el valor diverso de las diferencias entre las "regiones" de España - en algunos casos, tan claras y distintas -, al tratar el caso de Cataluña hay que hacer de nuevo una excepción. Porque Cataluña es un caso único dentro de España.» ${ }^{4}$

Horst Hina's book has related how various members of the generation of 1898 reacted to the aspirations of the Catalan people. The attitudes described range from ambivalence, or rather ambiguity, to hostility. Often the complexity of feelings occur within individuals themselves. It would appear that the image of Catalonia among Castilian-oriented writers is indeed blurred.

3 Julián Marías, Consideración de Cataluña. (Barcelona: Aymà, S.A. Editora, 1966) pp. 163-164. (All subsequent citations from this work will be from the same edition and will appear with the number of the appropriate pages in parentheses following the quotes).

4 Maurici Serrahima, Realidad de Cataluña, Respuesta a Julián Marías (Barcelona: Aymà, S.A. Editora, 1967) p. 36. 
Hina has described with care the individual reactions of the writers of the generation of ' 98 toward "la cuestión Cataluña». Even those who are sympathetic, like Azorín, for example, will side with Castile when there is any type of controversy, or merely differences of opinion. The favorable view of Catalonian aspirations must not interfere with Castilian self-interest: "Un documento interesante ... es el reportaje que hizo Azorín en 1906 para $\mathrm{ABC}$ sobre Barcelona... el tono general del reportaje es de respeto y admiración, de fascinación en vista de la dinámica y la actividad de la metrópolis catalana... A pesar de su admiración por Cataluña toma siempre partido por Castilla cuando ésta es atacada." (313). Unamuno, who had appeared to be favorably inclined toward Catalonia, (actually he was only when the question of Catalonia was aligned with that of the Basque people), took exception to Azorín's journalistic vision of Barcelona: «... Unamuno ... cree tener que echar una reprimenda a Azorín por su actitud procatalana." Unamuno will actually go so far as to write, "No creo, sin embargo, en la solidaridad catalana... Al catalán le falta agresividad y le sobra sensualidad..." (313). Baroja, of course, was his usual hostile self when it came to Catalonia. He was especially resentful of their bourgeois way. Their industriousness wass, as far as Baroja was concerned, a terrible failing. Hina relies on a number of references to Baroja's work to prove the "desprecio que Baroja sentía por el movimiento catalán burgués..." The one quote that stands out is from Baroja's Desde la última vuelta del camino; it deals with a catalan who had been an anarchist in his youth. Baroja meets him again "fifteen or twenty years later."

$-¿ \mathrm{Y}$ ahora? (asks the author)

- Ahora, mire, no pienso en tonterías, sino en ganar dinero.

- Hace usted bien, muy bien.

Después pensé: éste me va a hablar del catalanismo, y como no me interesaba la cosa, le dije:

- Bueno. ¡Adiós!

Y sin más, me separé de él y me marché al hotel. (325) 
More a disconcerting than Baroja's concept of Catalonia as a people who lust for money is the unfortunate position of a revered scholar like Ramón Menéndez Pidal. The eminent philologist also attributes to Catalonian aspirations for autonomy the profit motive. As Hina explains: "A causa del profundo carácter español de Cataluña le parece absurdo a Menéndez Pidal hablar en favor de los deseos catalanes de autonomía... Las tendencias regionalistas y nacionalistas puede explicárselas el historiador en el mejor de los casos por el afán de ganancia de los industriales barceloneses..." (32I). Baroja's extreme prejudice towards Catalans should not come as a surprise; he has already maligned other "nations"; his vituperations against the people of the Old Testament are shamefully remembered. (The author of this paper in 1952 had occasion to confront Baroja with his reviling commentaries on the Jews; his defensive position was that he had written such canards to ingratiate himself with the Nazis while he lived in France during the "occupation". The fact is that long before the forties he had also made similar scurrilous statements.) However, Baroja aside, that the beloved Menéndez Pidal, in some areas a veritable oracle, should have had such a perception that reduced Catalan quest for recognition of its irreductible identity to greed is quite disheartening. His unfortunate bias reflects poorly on Castile. His career as an historian began as a reaction to his student's first publication of España en su historia: moros, cristianos y judios; perhaps he was in too much haste to oppose Américo Castro's new concept of Spanish history.

Salvador de Madariaga, in his book España, displays clarity of thought in much of what he writes, but not on the subject of Catalan oneness. Again, we have the insistence on the materialistic character: «El catalán revela firme asimiento de los aspectos materiales de las cosas... El catalán siente siempre en sí formas implícitas que piden materia en que tomar cuerpo para pasar así de la mente el espacio".5 To be sure, Madariaga's perception is largely

S Salvador de Madariaga, España, ensayo de bistoria contemporánea. (México, 
philosophical; still, the vision of materialism prevails. Another assertion of Madariaga implies that Catalonia lacks a sense of history, that it is absorbed only with the present: "Cataluña quiere recoger la ruta del progreso. Deja a Castilla la eternidad y se contenta con el tiempo, y en particular con el tiempo presente, tal y como se manifiesta en los varios objetos de la vida cotidiana". (213). His explanation for the linguistic dependency of the Catalonian language upon Castilian rests on there also being two verbs "to be" in Catalan as well as in Spanish: «... un lenguaje español... Confirma esta conclusión... La existencia de esta distinción en el lenguaje catalán bastaría para demostrar que es uno de los lenguajes de la familia española..." (216). Stylistically speaking, Madariaga's persistent reference to Catalan as "lenguaje» is revealing, that is, it is revealing of his inability to accept Catalonia as a meaningful entity, with a language of its own.

To the Catalan intellectuals it is no secret that they dwell within a mystery that tends to foster myths. The conception of static realities about Catalonia, such as being a money-driven area, another "patria chica", another Spanish "región", or being just like the Basques, will not astonish, but merely perplex the $\mathrm{Ca}-$ talan intelligentsia. A very interesting book, Cataluña: esa desconocida para España, contains a number of journalistic pieces on the subject. The struggle for identity is interminable - and at times seemingly hopoless; the enemy is assimilation. "Por ello, a través de las páginas de este libro intentamos presentarnos como somos y sentimos, con el íntimo deseo de que los no catalanes, en vez de molestarse por el hecho diferencial que Cataluña presenta, dentro de la latinidad en que estamos inmersos, nos acepten sin intentos de castellanizarnos." "It would appear that the Catalans'

Buenos Aires: Editorial Hermes, sexta edición: 1955), p. 211. (All subsequent citations from this work will be from the same edition and will appear with the number of the appropriate pages in parentheses following the quotes).

${ }^{6}$ Club Arnau de Vilanova, Cataluña, esa desconocida para España, A propósito 
resistance to assimilation has been, at the same time, their domm and their blessing. Forced alienation, born out of ignorance and hostility towards noncoformity on the part of detractors, has instilled in the Catalan people a sense of contumacious pride in their own heritage. There seems to be an interesting correlation between persecution and pride; the more they are the objects of disdain and interdictive edicts, the greater their vainglory. Defensiveness makes patriotism shine. Foes will consider such a posture as chauvinism; friends will be sympathetic. The problem exists because the former by far outnumber the latter.

It is probably natural that a majority should resent having a minority take pride in their differentiation from "the norm". Yet, the Catalans stoutly maintain and rejoice that they are "different". One of the articles in Cataluña: esa desconocida para España is entitled "El hecho diferencial está ahi". In it, its author, Josep M. Puigjaner, happily celebrates the uniqueness of Catalonia in all possible ways, including the landscape. Moreover, he makes the point that not until non-Catalan Spaniards make an effort to learn the Catalan language, as Catalans are expected to learn Castilian, will a significant step have been taken toward mutual respect and understanding. "El día en que a los españoles no catalanes se les ocurra que sería fascinante aprender catalán se habrá dado un gran paso adelante.» (25). That the Catalans regard their language as worthy as any other not be more surprising than is their perception of their land as a nation rather than a mere region. While other Spaniards will think of their native place as their "patria chica", the Catalans think of theirs as "una nació".

"¿Es Cataluña una nación?» by Josep Maria Ainaud de Lasarte is another question which is addressed in Cataluña: esa desconocida para España. The presentation is obviously rhetorical. The

de 200 artículos de prensa, Prólogo de José Luis Aranguren. (Barcelona: Ediciones Península, primera edición: mayo de 1983), p. I6 (All subsequent citations from this work will be from the same edition and will appear with the number of the appropriate pages in parentheses following the quotes). 
fact is that Catalans have little patience with fellow Spaniards who do not understand this issue: "Comprendemos que la explicación "Cataluña es una nación" sea incómoda para aquellos que han mantenido, a lo largo de los años, que nación sólo hay una: España. Son las mismas personas que negaban la condición de idioma a la lengua catalana y afirmaban, sin miedo al rídiculo, que el catalán era un dialecto." (5I) The Catalan position, of course, is that Catalonia is and has always been a nation. The claim has historical and legal bases: the supportiveness of the past relies on the isth century when Cardinal Margarit, along with the chronicler Zurita, insisted on the national characteristics of Catalonia; the strength of present recognition of this situation is found in the reigning constitution which affirms the nationality ("la nacionalidad") of Catalonia. While this may seem like a far cry from accepting Catalans as members of a nation, actually it is a step in the right direction. Such a denomination leaves behind the anachronistic, banal, Castilian epithet, "region". Now the problem lies with the many non-Catalan Spaniards who refuse to respect this reality which has a foundation that is both legal and moral. Static realities die hard. There hardly exists evidence that non-Catalan Spaniards, intellectuals or not, have been able to enter into the process of demythification. The prejudices of earlier generations haunt and possess the living.

The anger of Catalan writers directed toward those who have adamantly refused to acknowledge the uniqueness of Catalonia is unequivocally expressed by Anscari M. Mundó in his "Anotaciones a la ignorancia histórica». He lashes out quite hard at the politicians in particular. According to the author, the geographic concept of Catalonia dates from the 8th century, and the historical one from the irth century. Already in their "diàspora", since the time of Oliba, the founding father who lived in the early part of the eleventh century, Catalans have referred to their "patria" as "nació". To be sure, at all times non-Catalan Spaniards have been welcomed to Catalonia, and the national characteristics of those living under Castilian hegemony have been respected-albeit as 
those another nation. What the Catalans are asking is corresponding reciprocity, courtesies returned in kind. At times a feeling of despair has been manifest among frustrated Catalans who are at a loss to understand such illogical behavior on the part of the majority.

It would appear that time might have somewhat corrected the legal inequities that have beset the Catalan people. At least, they are legally recognized as a "nationality". Nonetheless, the naked truth is that Catalonia at best continues to be perceived as a strange entity; at worst, it is still viewed as just another "región", with its own particular substandard language, a dialect, really. When added to this pejorative vision, we find the unflattering notion, which even when comically presented is no less pernicious, that Catalans are a greedy, money-minded people, we confront an ugly prevailing reality that camouflages comfortable ignorance, and possibly a feeling of monstrous envy. The exaggerations, which often become distortions, do little to assuage the dialogue of contentiousness that has become to some extent characteristic of Catalan and non-Catalan Spaniards' relations. On the contrary, traditional static prejudices serve to create a sort of cultural iron curtain. The spiritual distance creates an air of mystery for the non-Catalans Spaniards; not so for the Catalans, who continue to master the Castilian language with pride and determination. If the non-Catalan Spaniards lack the ability to grasp the consonant duality of Catalan existence, certainly the Catalans suffer no deficiency in the appreciation of Castilian historical accomplishments, including the establishment of an hegemonical empire. What most bothers the Catalans' fellow Spaniards is that Catalonia should not have yielded to the might of this empire. Catalan persistent resistance to overwhelming national power, as well as the celebrations of their own cultural heritage, contributes greatly to their being viewed as «a strange people». Different from the Basques, they are not un-Spanish; unlike non Catalan-Spaniards, they do have their own nation within Spain. The truth be said, their situation, a duality of allegiance to two na- 
tions, cannot be easily comprehended. Indeed, the concept is no less painful to embrace than is bilingualism for committed monolinguals.

ROBERT KIRSNER

UNIVERSITY OF MIAMI 